\begin{tabular}{ccc}
\hline International Journal of Engineering \& Technology, 7 (4.7) (2018) $458-462$ \\
SPC & Website www.sciencepubco.com/index.php/IJET \\
Research paper & Technology \\
\hline
\end{tabular}

\title{
Understanding the Meaning of Triangular Shape in Mosque Architecture in Indonesia
}

\author{
J. Jamaludin ${ }^{1 *}$, Purnama Salura² \\ ${ }^{1}$ Interior Design Department, Institut Teknologi Nasional Bandung Indonesia \\ ${ }^{2}$ Department of Architecture, Universitas Katolik Parahyangan, Bandung, Indonesia \\ *Corresponding author E-mail: jamal@itenas.ac.id
}

\begin{abstract}
This paper discuss the formal and symbolical meaning of triangular shape of contemporary mosque architecture in Indonesia, with case study the mosques designed by Ridwan Kamil in Jakarta and in rest area $\mathrm{Km} 88$ toll road between Jakarta and Bandung. There was a question in the public whether the triangular shape was adequate to be used as a mosque building. This paper propose answers with the analitical descriptive to understand the symbolical meaning of triangle shape used Sundanese community culture, one of Indonesian ethnics as representation. The paper used comparation and interpretation method to reveals the meaning of triangle shape in local culture and to find the connection to triangle shape in contemporary mosques architecture. The vernacular mosques in Indonesia known with their pyramid shape stacked roof with pointed roof in the peak. The pointed roof derived from the mountain that believed as the sacred place and used as symbol in the form of stacked roof of mosque. The finding of this paper is that triangular form can be accepted as mosque architectural form for the symbolical meaning derived from Sundanese culture. In the two mosques, this triangle shape enlarged and become praying room and as bridge to the God realm. The shape then achieved two purpose, as symbol of holy place and also fullfiled the function of praying room.
\end{abstract}

Keywords: triangular shape, mosque architecture, meaning

\section{Introduction}

In present day, the development of new mosques in Indonesia show the significant progress. From observation during short travels to some cities and Lombok island with its slogan the thousand mosques island, the architecture style of new mosques mostly dominated by Arabic or mid-east style. Middle Eastern architectural style is generally characterized by the presence of domes and minarets. If distinguished by the roof model, generally mosques in Indonesia are divided into three typologies.. First, mosque architecture that use the mid-east style, second that use the local or vernacular style. The most striking difference is on the roof. Middle east style generally uses domes on the roof, while local or tropical styles use a tropical roof in the form of a four-sided sloping roof or pyramid hip roof in simple style and pyramid-shape stacked roof in more advance style.

The third is an architectural style appears that does not resemble the two, but is a mixture of various contemporary ideas produced by architects in their search for new modern ideologies of mosque architecture. One of the architect with this approach was the late Achmad Noe'man with his work Salman mosque in front of ITB campus Bandung. This mosque stand alone, it doesn't used dome of arabic style or roof as tropical identity. However, Achmad Noe'man placed one modern minaret (tower) in the south-east of mosque. This tower is the most of visible aspect of mosque [1].

One of the architects today that uses this approach in a more advance creativity can be said is Ridwan Kamil. He graduated from Department of Architecture ITB and took master degree in Urban Design, University of California at Berkeley. After graduated from
UC at Berkeley, he worked in Skidmore, Owing and Merril (SOM), the prominent architecture office in USA, and when returned to Indonesia he opened design office Urbane Indonesia. He designed various building such as house, high rise office, campus, including mosque. One of his work is Al Irsyad mosque in Kota Baru Parahyangan West Bandung. He used box style without dome or tropical roof with three wall decorated by callygraphy of Syahadat in large size. This mosque immediately attracted public attention because of its unique and different design.

$\mathrm{He}$ also designed West Java great mosque in Bandung that surrounded by lake and now under construction. There are two other mosques with different form that used A-frame construction or triangular shape-base. These two contemporary mosques invite questions from the public about whether a triangle or A-frame is a proper form for a mosque building. At first, the mosque management rejected the design because it doesn't use a dome roof but instead a triangular shape. Ridwan Kamil explained his design concepts that the roof was imitated the tropical roof and the mosque management accepted the design [2]. The second, when the mosque was completed, there were local resident refused to use the mosque because for them it looks like a church. The mosque management then explained that the architect of the mosque is Ridwan Kamil, who also designed mosques in other places. This explanation made the local resident accepted and use it for worship purposes [3].

The case above shows that the problem of meaning of triangular shapes on mosque architecture has not been widely understood by many people. The community still considers that the roof of the mosque must be dome-shaped, even though there are no rules about 
it. Thus the triangle shape in the mosque must receive in-depth attention and research to get an explanation that can be understood by the public.

This paper aim is to unveil the symbolic meaning contained in the A-Frame shape or triangle shape in mosque architecture in Indonesia. With this analysis, it is expected that there will be benefit in form of an understanding of the triangular shape applied in the form of a mosque building, both architectural and interior design. By understanding the meaning of triangular shapes in mosque buildings, in addition to the community can understand the wealth of symbolic elements in mosque buildings, also the opportunity is wide open for architects to make mosque designs in various forms according to cultural diversity in Indonesia.

\section{Materials and Methods}

The case study of this paper is two mosques architecture designed by Ridwan Kamil. One of the mosques is Jami'e Darussalam in Kotabumi Ujung street, Kebon Melati, Central Jakarta, the second is in a rest area $\mathrm{km} 88$ of toll road Cipularang, between Bandung and Jakarta (see figure 1) both in west part of Java island. Darussalam mosque building consists of two floors, the ground floor used for management and commercial space and the upper floor is used as a mosque. The mosque used triangle shape that in architecture called A-frame construction for the all entire building and creates the isosceles triangular prism interior of the mosque. At the end of the west side (qibla direction) there is a painted white frame to mark the area of the mihrab.

The mihrab wall decorated by kufic style callygraphy and the rest cover up with glass framed with triangle shape composition. Daylight comes in from tilting window glass parallel to the A-frame construction of steel. This windows glass is decorated with calligraphy. In the facade there are circular and square shape composed shape filled by calligraphy.

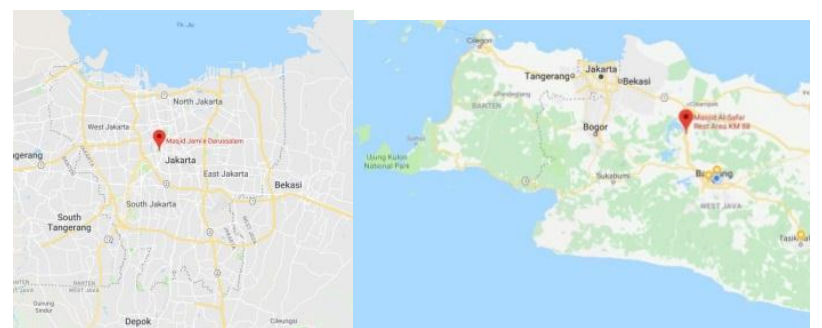

Figure. 1: Left, location of Al Safar mosque, in rest area $\mathrm{Km} 88$ toll road between Jakarta and Bandung; Right, location of Darussalam mosque, Kebon Melati, Central Jakarta
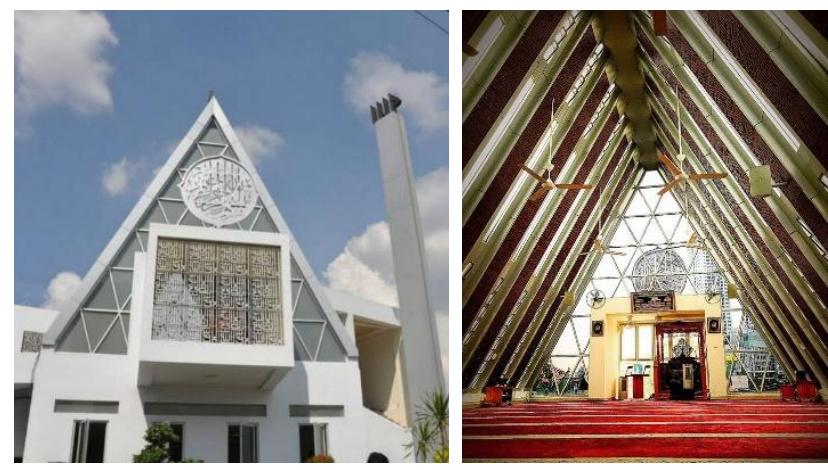

Figure. 2: Exterior and interior of Darussalam mosque with A-frame construction that is triangle shape. A-frame construction created isosceles triangular prism interior. The cantilever box is mihrab area.

For Al Safar mosque, Ridwan Kamil composed of triangle shape to form the sloping wall of the building with Aluminium Composite Panel (ACP) rectangular module. The interior of this mosque is gradation forms from reactangular to triangle form or A-frame in the west end or mihrab. There is no window except in the left and right sloping wall of mihrab there are tall vertical windows to let day light entering the room and creates bright ambiance of the imam area.
For the convenience of air, the mosque is equipped with air conditioner. The form concepts of $\mathrm{Al}$ Safar derived from traditional Sundanese headband but also consists of diamond cut shape [4].
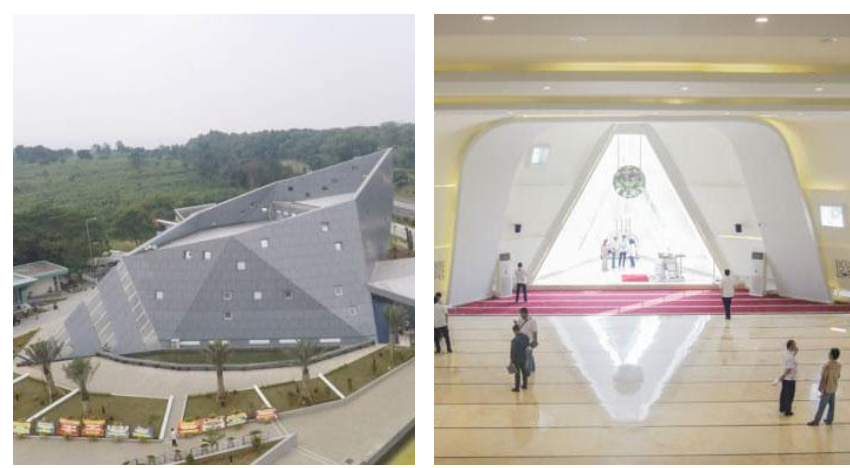

Figure 3: Exterior and interior of Al Safar mosque. Wall composed by triangle composition using ACP. The mihrab area with day light comes from left and right side window

To reveal the meaning of triangle shape in Darussalam mosques and Al Safar mosque in Indonesian cultural context, comparation method used between Indonesian vernacular mosque with Darussalam and Al Safar mosques. The aim of this method is to find similarities and differences between the model of the mosques. The main goals of design is the aesthetic. There are two kind of aesthetic, formal and symbolic. Formal aesthetic is the study of structure of forms, and the symbolic aesthetics in the study of human responses to the content of forms [5,6]. In architecture, formal aesthetics is mainly focused with the appreciation of the forms, shapes, rhythms, complexities, composition of objects, and sequences of the visual world.

Symbolic meaning generally refers to the image and associations that come to mind in regard to an object. Object can act as symbols for humans, providing personal meaning and communicating the owner's personal characteristics to others The meanings that we attach to products play an essential role in how we feel about them and evaluate them[7]. A symbol is something that stands for something else[8]. It may do this as result of an association, a convention. A symbol is the result of a cognitive process whereby an object acquires a connotation beyond its instrumental use. An object may be an environment. Its meaning are derived from what an observer imputes to them [9].

To understand the aesthetic meaning of the object, this paper used the method of interpretation. According to Robert Stecker [10], the method of interpretation of art is the effort to understand or appreciate a work of art or to increase the level of understanding and appreciation. Some views in the interpretation method used in this study is the actual intentionalism and the meaning of the work. Actual intentionalism is the view that the proper interpretation of a work of art can identify the artist's expression goals in his work, both semantically and symbolically. The steps to interpretate of this case that is to find the same or similarity shape in vernacular mosque architecture in Indonesia and to find the meaning of the triangular shape in the Indonesian ethic culture connected to triangular shape in Darussalam and Al Safar mosques. The Sundanese ethnic culture will be used as representative of Indonesian ethnic culture due to the location of mosque is in West Java, where the Sundanese ethnic live.

\section{Results and Discussion}

To trace the source of the triangular shape in Darussalam mosque and Al Safar mosque, a study of the theoretical framework on the concept of Indonesian mosque form was conducted, and used to find out the relationship between the concept of architectural forms of the two mosques and the concept of triangular shape in Indonesian with Sundanese ethnic culture as representative. 


\subsection{The Origin of Triangle Shape in Architecture}

The description below is a way to understand the triangle shape in building. In art, architecture and design, shape defined as two dimensional and form is three dimension. In other word, shape is a flat two-dimensional area enclosed by lines and form is a three-dimensional area enclosed by a surface [11]. Triangle shape in term of art consists of two dimensional shape that is in architecture generally called A-frame construction. It derived from letter " $\mathrm{A}$ " and performed triangle with the same leg or called isosceles triangle [12].

Isosceles triangles, which have two equal sides, are also found in architecture throughout the world, mainly in traditional house. The triangle's use in vernacular architecture dates back more years than other common architecture shapes such as the arch, dome, and cylinder.
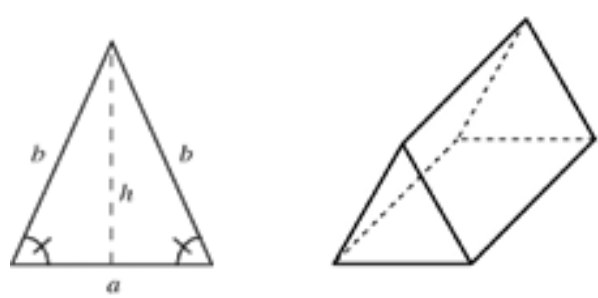

Figure 4: Isosceles in three dimension created isosceles triangular prism (A-frame)

The A-frame in house construction, is not a new approach and it has a long history. According to Chad Randl [13], A-frame buildings are an old form that can be found in some region in the world such as Europe, China, and the South Pacific islands. This A-frame were simple structures used for utilitarian purposes until the 1930s. Chad Randl explained that "A" is the architectural letterform of leisure building and popular in postwar America. The A-frame is an easy and affordable home to construct in retreat area such as mountain and lakeside, its steeply sloping triangular roof distinctive and easy to maintain. This construction featuring steeply-angled sides (roofline) that usually the two wall of triangle begin at the foundation line, and meet at the top in the shape of the letter A.
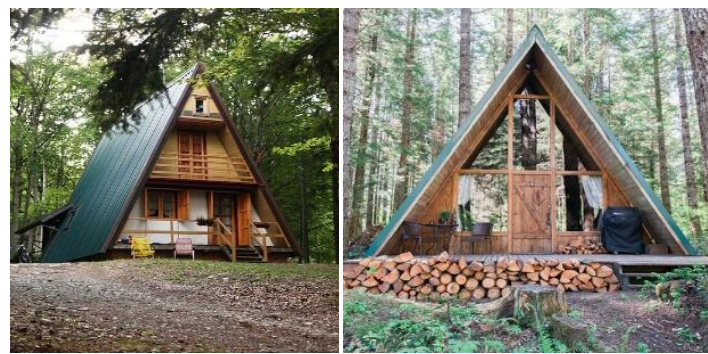

Figure 5: A-Frame house (pinterest.com)

From description above it is clear that triangle shape or A-frame shape is a common form of house and did not derived from church but it is also applied in any other building including church architecture. What Ridwan Kamil has done was created isosceles triangular prism room was he applied the form into mosque that can be used by congregation for praying.

\subsection{Tiered Roof of Vernacular Mosque Architecture in Indonesia}

In Indonesia, the roof of traditional or vernacular mosque generally composed by tiered roof or pyramid-shaped form stacked roof [14] This is common form mostly in main island such as Java and $\mathrm{Su}-$ matera island and becomes one of typology of Indonesian vernacular mosque architecture. Referring to nature, the pointed shape is the common shape of the mountain. This mean that pointed roof or pyramid hip roof style imitated the mountain shape and can be easily connected to the mountain because of the same shape. The Javanese mosque was derived from mount form [15]. The meaning of triangle shape or pyramidal roof in tiered roof of in Indonesian vernacular mosque is regarded as the representative of meru, a sacred mountain.

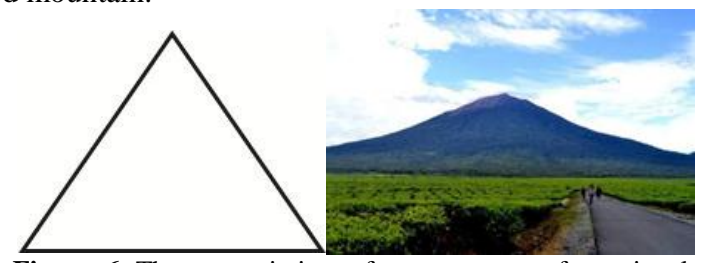

Figure. 6: The mountain is a reference to nature for a triangle

Javanese mosque generally have two to five stacked roofs. Five tiered roof levels as found in Banten great mosque featured moslem faith as follows: the bottom level is the largest roof represent all moslem (islam), the second level is faithful (mukminin), the third represents benefactor (muhsinin), the fourth represents sincere (muhlisin) and the fifth roof represents the cautious (muttaqin) [16]. In Java island, the most common mosque is three stacked pyramidal roofs, it represents trilogy of islam treatise, those are faith (iman), surrender (islam), good deeds (ihsan). The basic shape of stacked roof is triangle and formed pyramidal form in three dimensional form.
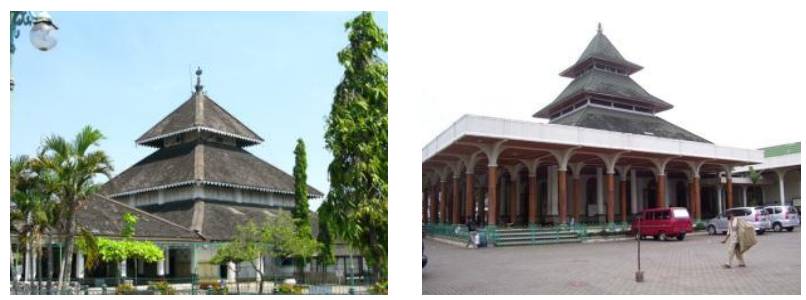

Figure 7. Indonesian vernacular mosque with the pyramidal stacked roof

\subsection{The Meaning of Mountain in Indonesian Culture}

The mountain plays an important role in the history of ethnics in Indonesia, in particular because of the various megalithic sites and sacred tombs commonly found on the mountain. Wessing [17] further reveals the Hidding research (1933 and 1935) that mountains are the boundary between the settled area and the foreign territory where human life ends and other lives begin.

According to Moh. Ali Fadillah [18] a number of sacred, especially in the form of a tomb, although not on the top of the mountain but is a representation of mountain or imagined as a mountain. Fadillah using the example of Sharif Hidayatullah tomb in a hill called Sembung in Cirebon West Java, the community called it Sunan Gunung Jati. This also mentioned by Claire Holt [19] that the top of a mountain peak in Indonesia is widely believed to be the abode of the gods and ancestral spirits. Also the volcanoes are considered to have their own life and spirits, adored and respected. The mountain is considered a bridge or gate from the world to the god realm, from life to the hereafter, from mortal to immortal life, therefore the places of worship established in high places or made to imitate the form of mountain (gunungan) such as punden staircases and temples and pyramid as transcendental bridge between the underworld (human world) and the upper world (God realm). In the Hindu-Buddhist view, the mountain is considered to play a role in stabilizing the universe, supporting the heavens and the earth, neutralizing evil forces, chaos, instability and disorder. The mountain is the symbol of supreme power and as a binder of the universe [20].

This piramidal shape is taken from mountain in three dimensional form and triangle shape in two dimensional view. As symbol of sacred place, the mountain miniatured in the peak of the mosque. 


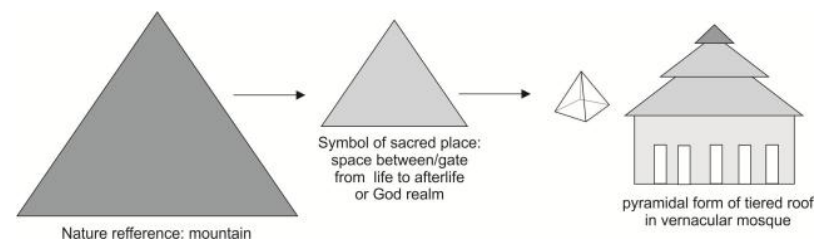

Figure 8: Mountain is understood as a holy place, abstracted in the form of a triangle and interpreted as a holy place

\subsection{Meaning of Triangle Shape in Sundanese Culture}

In Sundanese language, the triangle shape can be found in the phrase bale nyungcung (building with pointy roof) and Buana Nyuncung (pointy realm). Bale Nyungcung is another name for the holy building, which is mosque. In old days, sentence in Sundanese ka bale nyungcung (go to the mosque) in everyday conversation means "to hold the marriage ceremony", which is generally done in the mosque. Bale nyungcung pointed to the model of the roof of the mosque that uses a gunungan (mountain-look shape) or meru piled with tiered roof with pyramid-shaped on top composed of four triangular shapes.

In the Sundanese cosmology adopted by the Kanekes community, according to the Carita Parahiyangan script is called Jatisunda realm is divided into three types[21], they are:

(1) Buana Nyungcung, or Buana Jatiniskala the place where God resides, which is located at the top,

(2) Buana Panca Tengah or Buana Sangkala a place where human and other creatures live, located in the middle,

(3) Buana Larang, or Buana Niskala which is the place of people who have passed away.

The term Buana Nyungcung is the zenith universe, a term in Sundanese cosmology for god's place [22]. Pointy buildings and pointed realm are interpreted as sacred buildings not because of their sharpness but because the pointed part is pointing upwards. The upward direction is interpreted as a place of omnipotence, the place of God. The term nyungcung used to explain the highest place, the place that only suitable for God and thus it can be understood that nyungcung means holy place. The pointed shape symbolized by a triangle with one of the pointed sections located at the top and it real world it is mountain.

Mountain used as symbol as holy place for its function as the space between world and sky. In other world a space between real life in the world and the afterlife or realm of God that believed exist in the sky as heaven. Heaven is understood as an almighty place, which is why when praying people raise their hands up with open fingers.

The other meanings about triangle was told by Ajip Rosidi [23]. He explained that the triangle shape (in Sundanese called juru tilu) is also used as a symbol of the vagina or yoni, the gate or door for human birth. It seems that the symbol is in the form of an inverted triangle or one of the corners is located below. This triangle shape is opposite position with the mountain shape. The two triangle shapes abstracted from mountain and vagina then can be understood as the space beetween. Mountain is space between real life in the world and the afterlife or realm of God. The vagina is space between the nature of womb and the real life in the world. From the description above, it becomes clear that the triangle has an important role in human life, because it acts as a connecting space between the two worlds a place of transformation from the previous world to another.

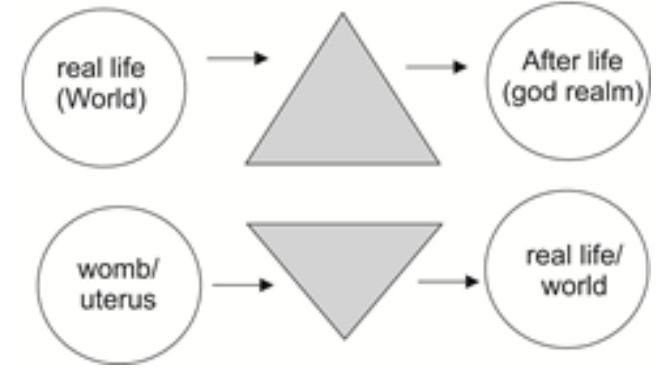

Figure 9: Triangular shape meaning in Sundanese culture, as space between or gate of two realm

\subsection{Comparation Study: The Meaning of Triangular Shape in Indonesian vernacular mosque and Darussalam Mosque and Al Safar}

What distinguishes the two mosques designed by Ridwan Kamil from the shape of the vernacular mosque's roof top, is that the two mosques are abstraction from the shape of a mountain into an Aframe construction, taken from the shape of triangular shape. By magnified the shape as seen in the two contemporary mosques, the triangle shape not merely symbolic but also become functional and formalism [24].

The triangle shape that applied in the form of tiered roof in the vernacular mosque merely symbolical form. The triangle shape in piyramidal form of stacked roof in vernacular mosque used merely as symbol, in Darussalam mosque and Al Safar mosque also created as space to pray. Ridwan Kamil enlarged the symbol into the isosceles triangular prism so that in addition to being a symbol of holy place, the triangular shape also plays as formal form for the functional object as space.

Two mosques designed by Ridwan Kamil do not used stacked roof as implimentation of the triangle symbol but he used the triangle shape into the space and the mihrab form. From description above, it is became obvious that two mosques designed by Ridwan Kamil also have a connection with this tiered or stacked roof meaning, but in contemporary implementation in the form of isosceles form.

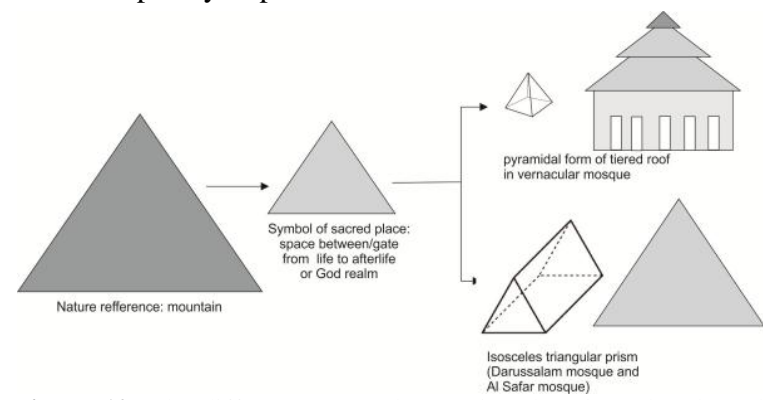

Figure 10: The different approach on using the triangular shape between Indonesian vernacular mosque and Darussalam and Al Safar mosques.

\subsection{Aesthetic Approach The Meaning of Triangular Shape of Darussalam and Al Safar Mosque}

The A-frame construction of Darussalam mosque building which then creates the isosceles triangular prism interior of the mosque, and triangle shape composition in the exterior and in mihrab area in Al Safar mosque, can be understood as the adaptation the symbolical interpretation from local culture into the mosque contemporary architecture. Ridwan Kamil enlarged the triangle shape into an isosceles triangular prism created space that can be used by congregation for praying. It does not only as a symbol but is manifested into buildings. In the vernacular mosque the triangular form is only placed at the top of the mosque, by Ridwan Kamil the triangular shape turns into a space for worship activities.

The meaning of triangle form in Darussalam mosque and Al Safar are quite the same. They are simbolised the holy place and also the space between life and god realm as the stacked roof in Indonesian vernacular mosque. 


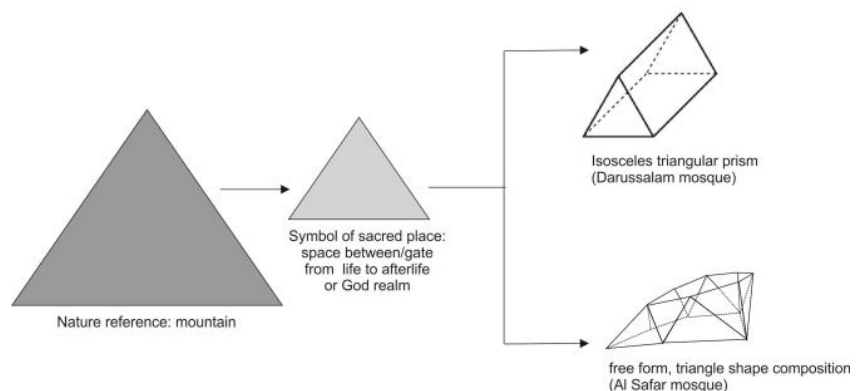

Figure 11: The mountain abstracted into triangle shape and applied to the isosceles and free-form composed by triangle shapes

\section{Conclusion}

From the result and discussion on the meaning of triangular shape in Indonesian moque and Sundanese culture, this paper concluded as follows. Firstly, the triangular shape can be accepted as the form of mosque architecture, due to the meaning of the triangular shape in Sundanese culture and also has relation to the symbolical meaning in Indonesian vernacular mosque. Secondly, from formal aesthetic approach revealed that the triangular shape does not derived from church architecture but as A-frame construction that could be found in vernacular architecture and the common roof style in tropical region. Thirdly, architectural form of Al Safar mosque beside designed with the concepts of form derived from the Sundanese physical culture that is traditional headband and diamond cut chape, but with output that shows the triangle shape composition, could be related to the symbolical meaning of triangle shape in Sundanese culture. Fourthly, the results of this research could be used as an input that would enriched theoretical and empirical knowledge on the basic shape of contemporary architecture in Indonesia. Fifthly, study of the meaning of a form, will enrich the repertory of architectural forms, becoming more diverse according to the very colorful Indonesian cultural conditions.

\section{References}

[1] Kendra Weisbin, "Introduction to mosque architecture," https://www.khanacademy.org/humanities/art-islam/beginnersguide-islamic-art/a/introduction-to-mosque-architecture, accesed August 7, 2018

[2] Sakinah Ummy Hany, "Masjid Darussalam, oase di tengah kebisingan Jakarta", https://www.rappler.com/indonesia/136617-masjid-jamie-darussalam-ridwan-kamil Juni 16, 2006, retrieved April 20, 2018.

[3] Kumparan, (2018) "Masjid Segitiga Tanah Abang, Karya Emil yang Pernah Ditolak Warga," https://kumparan.com/@kumparannews/masjid-segitiga-tanah-abang-karya-emil-yang-pernah-ditolakwarga, retrieved 25 August, 2018.

[4] Sigit Bowo, "Desain Futuristik, Masjid Al-Safar Rest Area 88 Cipularang Jadi Favorit Pengendara" https://bimasislam.kemenag.go.id/post/berita/desain-futuristik-masjid-al-safar-rest-area88-cipularang-jadi-favorit-pengendara October 2017, retrieved 15 August 2018.

[5] Jon Lang, "Symbolic Aesthetic in Architecture, toward a research agenda", in Environment Aesthetics: Theory, Research, and Application, ed. by Nasar, Jack L. Nasar, Cambridge University Press, (1992)

[6] Salura, P. (2018). The philosophy of architectural ordering principles. International Journal of Engineering and Technology(UAE), 7(2).

[7] Sari Kujala,Piaa Nurkka, Sentence Completion for Evaluating Symbolic Meaning. International Journal of Design, Vol. 6 No.3, 2012, 15-25. Retrieved 20 March, 2018.

[8] Salura, P. (2018). The philosophy of architectural ordering principles. International Journal of Engineering and Technology(UAE), 7(2).

[9] Gyorgy Kepes, Sign, Image and Symbol, (London: Studio Vista, 1966)

[10] Robert Stecker, "Interpretation, in Routledge Companion to Aesthetics", ed. by Berys Gaut, and Dominic McIver Lopes, London: Routledge, (2001)
[11] Mary Stewat, Launching the imagination: a comprehensive guide to basic design, New Yok: The McGraw-Hill Companies Inc, 2006

[12] Eric Weisstein, "Isosceles Triangle," http://mathworld.wolfram.com/IsoscelesTriangle.html, 2018, retrieved August 15, 2018.

[13] Chad Randl, A Frame, New Jersey: Princeton Architectural Press, 2004.

[14] Hugh O’Neill, “South-East Asia”, in The Mosque History Architectural Development and Regional Diversity, ed. by M. Frishman and Hasan-Uddin Khan, London: Thames and Hudson, 1994, pp.224-240.

[15] Bambang Setia Budi, "A Study on History of Development of Javanese Mosque Architecture, Part 1: A Review on Theories on the Origin of Javanese Mosque "Journal of Asian Architecture and Building Engineering 3 (1), 2004, 189-195, retrived 15 August 2018. https://doi.org/10.3130/jaabe.3.189

[16] A. Bahaudin , T.E. Darmayanti, "The Cultural and Architectural Heritage of The Banten Great Mosque" in Islamic Heritage Architecture, ed. by C.A. Brebbia and A. Martinez Boquera, WIT Press, Southampton, UK. (2017)

[17] Robert Wessing, "Telling the Landscape, Place and Meaning in Sunda," procceding International Conference of Sundanese Culture, ed. By Ajip Rosidi, Ekadjati, Edi S. Ekadjati., A. Chaedar Alwasilah, Bandung: Yayasan Kebudayaan Rancage, (2006) p. 450-474

[18] Moh. Ali Fadillah, (2006): "Pengultusan Orang Suci pada Masyarakat Sunda: Sebuah Kontinuitas Unsur Budaya”, procceding International Conference of Sundanese Culture, ed. by Ajip Rosidi, Ekadjati, Edi S. Ekadjati., A. Chaedar Alwasilah, (Bandung: Yayasan Kebudayaan Rancage),p. 419-432.

[19] Claire Holt, Art in Indonesia: Continuities and Change, (New York: Cornell University Press, 1967).

[20] Adrian Snodgrass, The Symbolism of the Stupa, Studies on Southeast Asia, (New York: Cornell University, 1985).

[21] Jamaludin, "The Aesthetic of Sundanese Traditional Design, case study: Rice Container design”, Journal of Visual Art and Design, ITB, vol 4. No 1, 2013, 35-41.

[22] Edi S. Ekadjati, Kebudayaan Sunda (Suatu Tinjauan Sejarah), Jakarta: Pustaka Jaya, 1995)

[23] Interview December 1, 2009

[24] Noël Carrol, "Formalism", in Routledge Companion to Aesthetic, ed. by Berys Gaut, and Dominic McIver Lopes, (New York: Routledge, 2001), p. 87-96 